\title{
A Mini Review on SARS-COVID-19-2 Omicron Variant (B.1.1.529)
}

\author{
Santhosh Kumar Ettaboina ${ }^{1}$, Komalatha Nakkala ${ }^{2 *}$, K. S. Laddha ${ }^{2}$ \\ ${ }^{1}$ Quality control, Aurex Laboratories LLC, East Windsor, New Jersey, 08520, United States. \\ ${ }^{2}$ Medicinal and Natural Products Research Laboratory, Department of Pharmaceutical Sciences and Technology, Institute of Chemical \\ Technology, Mumbai - 400019, Maharashtra, India.
}

Received 12 December 2021; Revised 26 December 2021; Accepted 29 December 2021; Published 30 December 2021

\begin{abstract}
The current world facing unpredictable problems with different variants of COVID-19; SARS-COV-19 is a significant lung infection caused by a coronavirus. Each type has one or more alterations to distinguish from each other. The viruses, including SARS-COV-19, continuously change the genetic code (mutations) during their genome replication. WHO labelled two variants in that we are experienced with delta (B.1.617.2) variant, now recently the omicron came (B.1.1.529) with highly mutatable strikes on it. So WHO predicted it is more dangerous than previous variants because of its mutatable capability. The mutatable strikes play an essential role in transmissibility. So there is a need to evaluate threatens raised with the new variant, so scientists are working on it. Till now, South Africa noticed major cases positive for the Omicron variant. Based on recent reports, the current paper summarized different properties of the omicron variant with others, including protein structure, diagnosis, spreadability, treatment, and potency of vaccines.
\end{abstract}

Keywords: COVID-19; Delta Variant (B.1.617.2); Omicron (B.1.1.529); Spredability; Treatment.

\section{Introduction}

SARS- COVID-19 is a highly transmissible infection; previous reports revealed that it was started in the earlier years (MERS-COV) [1], but later predictable people were identified with corona infection in December 2019 in Wuhan china, they reported pneumonia with unknown cause [2]. Afterward, the same cases were reported all over the world. Then WHO recognized it and named it COVID-19; positive people were increased day by day with the unpredictable spreading of infection throughout the world in March. The whole world was imposed lockdown due to the pandemic situation [3]. So from that time onwards, scientists worked on COVID and tried vaccines.

On the other hand, many of the variants were observed with the different protein sequences of the genome. The alpha (B.1.1.7), beta (B.1.351), gamma (P.1), delta (B.1.617.2), and omicron (B.1.1.529) variants are among the variants. These variants have different protein sequences; those were including alpha virus contain 4 spikes (A570D, D1118H, S982A, T71I), beta variant contain 6 spike protein (A701V, D215G, D80A, $\Delta 241, \Delta 242, \Delta 243$ ), gamma variant contains 8 spike proteins (D138Y, K417T, L18F, P26S, R190S, T1027I, T20N, V1176F), T19R, (V70F*), Delta variant comprise ten unique proteins on it those including T95I, G142D, E156-, F157-, R158G, (A222V*), (W258L*), (K417N*), L452R, T478K, D614G, P681R, D950N) and finally Omicron including 30 spike proteins (A67V, del69-70, T95I, del142-144, Y145D, del211, L212I, ins214EPE, G339D, S371L, S373P, S375F, K417N, N440K, G446S, S477N, T478K, E484A, Q493R, G496S, Q498R, N501Y, Y505H, T547K, D614G, H655Y, N679K,

*Corresponding author: komalathanakkala@gmail.com

http://dx.doi.org/10.28991/SciMedJ-2021-0304-10

> This is an open access article under the CC-BY license (https://creativecommons.org/licenses/by/4.0/).

(C) Authors retain all copyrights. 
P681H, N764K, D796Y, N856K, Q954H, N969K, L981F [4]. The omicron genotype has a maximum of 50 mutations, with 32 of them occurring in the spike protein alone. The spike protein helps the SARS-CoV-2 virus adhere to cells and obtain entry by forming projecting knobs on the membrane of the virus. They discovered a D614G change in the spike glycoprotein (S) in the delta form during the evolution of SARS-CoV-2 in humans; viruses with this mutation have become the prevalent circulating modified type in the SARS-COVID-19 pandemic [5]. Comparatively, delta variant cases were more than Omicron so far, but it may increase in the future. The protein sequence of the omicron virus and how it is different from other variants?

In the omicron variant, the spikes play a significantly important role in mutations to change its genomic sequence by that I will escape against body-produced antibodies (Immune Cells). The omicron variant compared with other variants is related to the mutations [6].

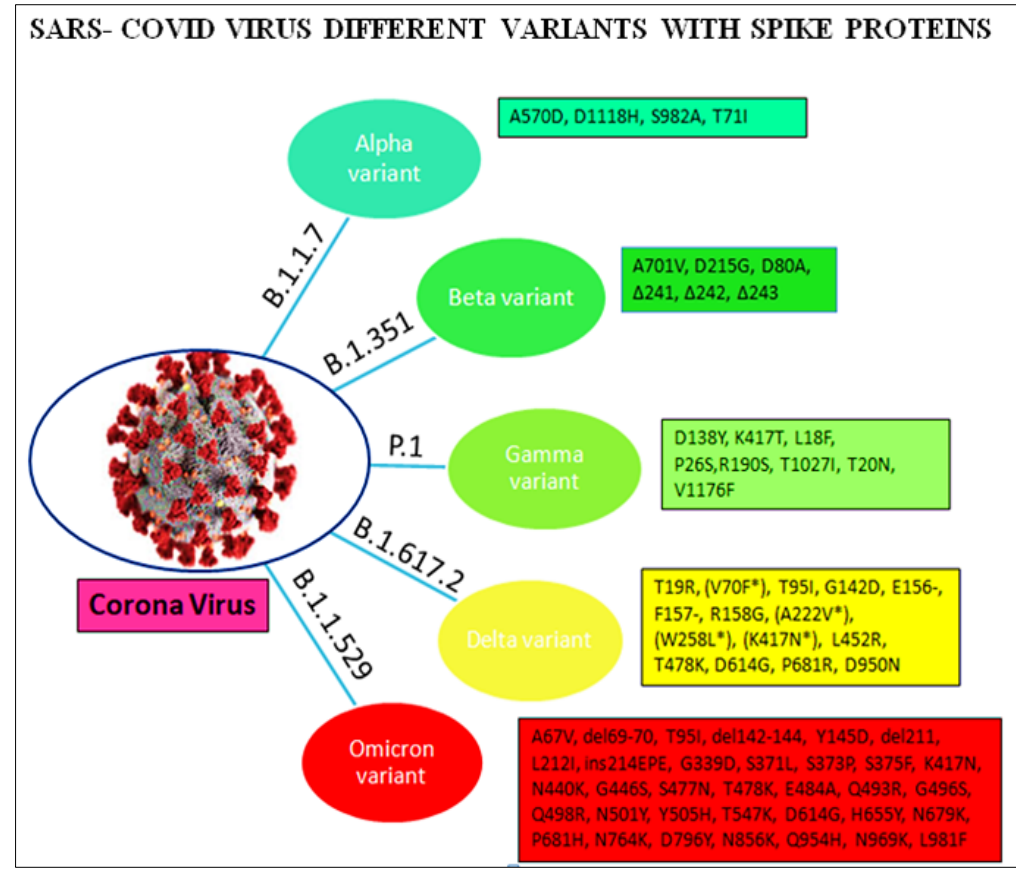

Figure 1. Different variants with their spike proteins

\section{Difference between Delta and Omicron Variants}

The Omicron variant has more mutatable capability than Delta; it doesn't mean it is more dangerous than other variants. So far, no new symptoms were reported due to the omicron variant; in the future, it may spread faster than other variants because of its mutations. The Figure 2 below mentioned expected spreading with mutations of the two variants, till now one death case reported due to omicron variant in UK [7] the virus that causes COVID-19, SARS$\mathrm{CoV}-2$, has the greatest mutations of any kind. We still haven't figured out how those genetic changes work. However, they remain for a reason: they aid in the success of a variety.

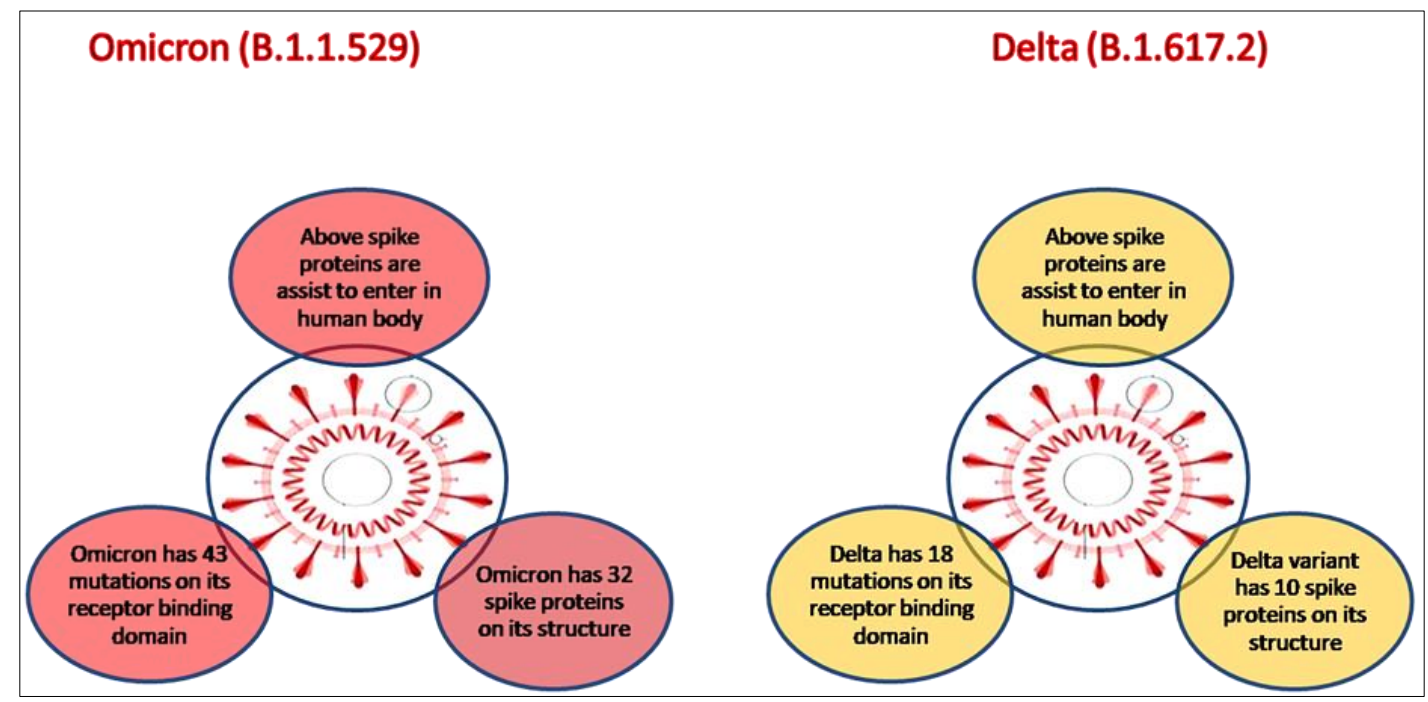

Figure 2. Different spike proteins between delta and omicron variants of SARS-COVID-19-2 


\subsection{Delta Variant}

Nine variations in the spike protein were observed, a protrusion on the virus's surface that aids in the virus's attachment to human tissues. According to Suresh V. Kuchipudi of Penn State University, who researches viral evolution, two are in a molecular hook called the "receptor-binding domain," which helps it attach to cells more tightly.

\subsection{Omicron Variant}

It's a mutation monster, with at least 32 mutations in the spike protein and ten in the receptor-binding domain [8]. On general, two or three people were infected with the first SARS-CoV-2 virus. Delta changed everything by infecting about six people. Delta has a four-day incubation period, which is lower than the six-day incubation period of the original virus, making people contagious sooner. The omicron's transmission rate and incubation period are unknown. Within the next few weeks, we will know better information about the omicron variant growth rates in other geographies [9].

\section{Diagnosis}

SARS-COVID-2infection was diagnosed reverse transcriptase-polymerase assay (RT-PCR), high-throughput genome sequencing, and serological evaluation of anti-viral immunoglobulin M (IgM), G (IgG) antibodies, and lung X-ray [10] (CT scan value). The food and drug administration (FDA) has approved two tests to diagnose SARS-COV2 infection. Those include:

\section{- PCR Test (also known as a molecular test):}

This COVID-19 test uses a lab technique called polymerase chain reaction to detect the virus's genetic material (PCR). A fluid specimen from infected can be collected with a nasal swab or swab from throat, or a saliva can be obtained by spitting into a tube. Results could be generated in less time if processed on-site or in a few days. The test processing delays, if evaluated off-site if transferred to an independent lab. The test give maximum percent precise results when done by a skilled professional; nonetheless, the fast results may be failure to identify few cases.

\section{- Antigen Test}

The COVID-19 test looks for the virus's specific proteins. The nasal swab used to capture a fluid sample, the results generation time was less. Others may be referred to a laboratory for examination. A positive antigen test result is considered accurate when procedures are followed correctly. Even yet, there's a larger chance of false-negative results, which means you could be infected but get a negative test. A PCR test may be recommended by the doctor to confirm either the person is positive for antigen test or negative, depending on the circumstances.

\section{- Lateral Flow Tests}

Rapid or lateral flow tests (LFTs) are currently performed, although they cannot tell you which variant you have; nonetheless, they are supposed to be able to tell you whether you are negative or positive, suppose you get a positive LFT result, self-isolate immediately, and get a PCR test to confirm the result.

\section{General Symptoms by SARS- COVID-19 including Omicron Variant and Spredability}

Fever, cough, running nose, body ache, loss of sensation (smell and taste) and difficulty in breathing in severe cases. On the other hand, they observed severe body ache, chills, dizziness, and mild fever [11], According to them, Omicron-positive people didn't have any breathing issues to date, and saturation levels remained normal.

\subsection{How fast is Omicron Spreading?}

Omicron is rapidly spreading in South Africa, particularly in Gauteng province, including Johannesburg and Pretoria. Testing has revealed that it is responsible for more than $90 \%$ of all infections. In the week ending November 30 , the seven-day average of daily cases in South Africa increased fourfold to 2,756. According to the WHO, the COVID omicron variant has been detected in 57 countries (December 15), [12] and based on preliminary data graph was drawn, this graph indicated reported cases were observed in top 5 countries and also in India (Figure 3), and the data was reported Table 1. In table we reported about reported omicron cases by daily news hunt South Africa [13], United Kingdom [14], South Korea [15], Europe [16], United States [17] and India [18]. According to South Africa's government reports more children got hospitalized with medium to high symptoms of omicron variant [19]. 
Table1. The reported data of omicron cases in the top 5 countries and India (Till Dec 15, 2021)

\begin{tabular}{cc}
\hline Name of the country & Omicron cases reported \\
\hline South Africa & 37875 \\
United Kingdom & $>10000$ \\
South Korea & 7000 \\
Europe & 766 \\
United States & 1500 \\
India & 653 \\
\hline
\end{tabular}

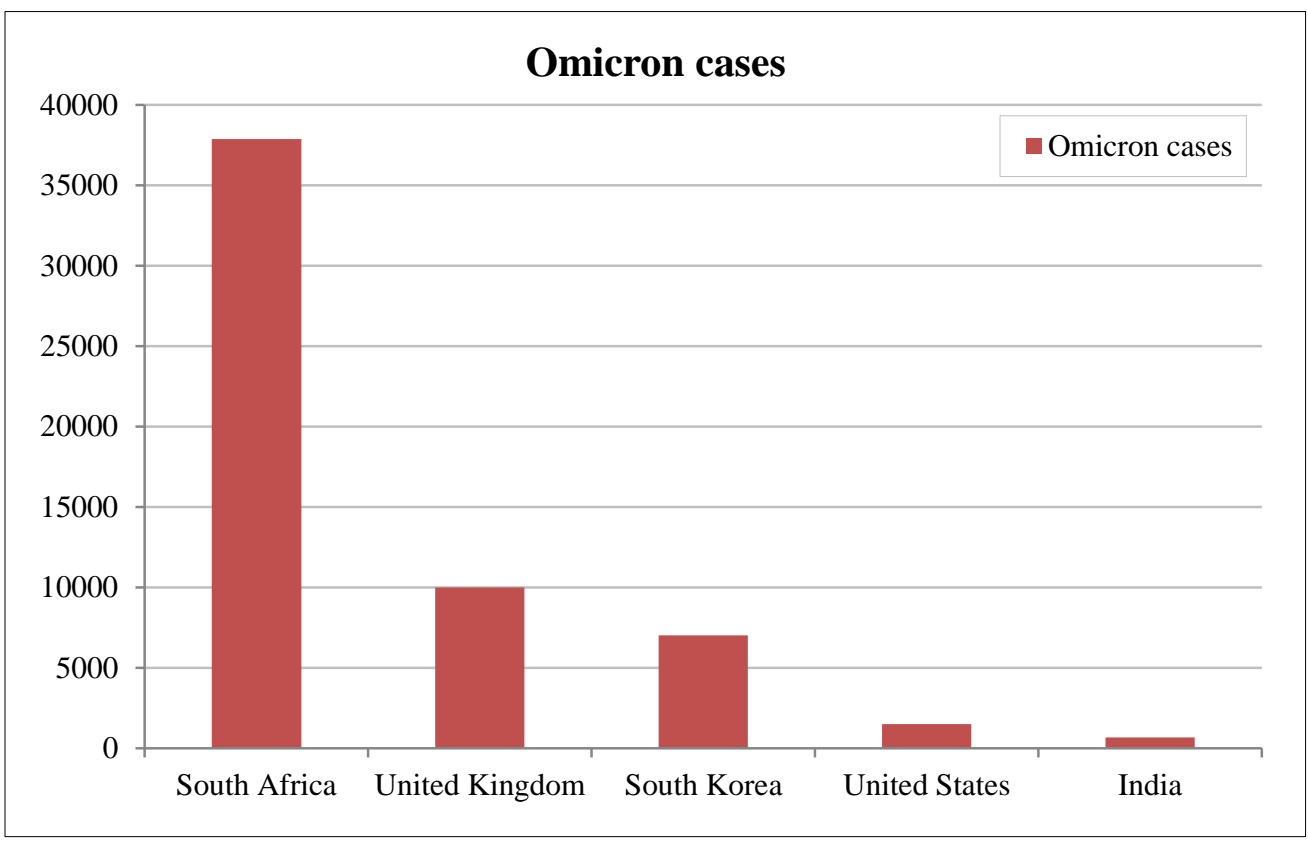

Figure 3. Reported cases of Omicron variant in top 5 countries and India

\section{Treatment of SARS-COVID-2 by Drugs}

SARS-COVID-2 in the primary stage, there is no need of takes any anti-viral treatment; in the initial stages, the virus load in the body is less usually so symptomatic relief and boosting of the immune system recommended by most of the physicians. If the patient's condition is worst, difficulty in breathing such situations, they advised anti-viral drugs. The list of anti-viral drugs used in the treatment of covid-19 is mentioned below.

Anti-viral medications like ribavirin and lopinavir-ritonavir [20] have been attempted with HIV, SARS, and MERS infection therapy based on anecdotal evidence. In case of the new variant the UK government-approved Xevudy or Sotrovimab as a medicine active against it. Xevudy or sotrovimab for those with mild to moderate COVID-19 and who are at high risk of developing severe disease, according to the Medicines and Healthcare Products Regulatory Agency (MHRA). Sotrovimab is an intravenous infusion that requires 30 minutes to complete and is recommended for people aged 12 and up who weigh more than $40 \mathrm{~kg}$. The MHRA stated that it is very early to confirm whether the Omicron variant affects the effectiveness of sotrovimab, but they intend to collaborate with the producers to find out [21]. Pfizer company confirmed nirmatrelvir pill was found to be effective against omicron patients [22] (severe cases).

\section{Vaccination Data}

The complete information about vaccines approved by countries was mentioned in Table 2 More than 4.32 billion people, or around 56.2 percent of the world's population, have received a dose of the Covid-19 vaccination. The vast disparity in immunization regimens in different countries is depicted in this map. In all over India, 33.7 population got fully vaccinated (Figure 4) [35-38]. 
Table 2. List of the approved Covid-19 vaccines

\begin{tabular}{|c|c|c|c|c|c|c|}
\hline S. No & Name of the vaccine & $\begin{array}{c}\text { WHO } \\
\text { approved }\end{array}$ & $\begin{array}{c}\text { No of the approved } \\
\text { countries }\end{array}$ & $\begin{array}{l}\text { How many trials in } \\
\text { how many counties }\end{array}$ & $\begin{array}{c}\text { Vaccine } \\
\text { type/Platform }\end{array}$ & Ref. \\
\hline 1 & Moderna: mRNA-1273 & Yes & 78 & $\begin{array}{l}33 \text { trials in } 8 \\
\text { countries }\end{array}$ & RNA & $\begin{array}{l}\text { Baden et al. } \\
\text { [23] }\end{array}$ \\
\hline 2 & Pfizer-BioNTech-BNT162b2 & Yes & 112 & $\begin{array}{l}46 \text { trails in } 21 \\
\text { countries }\end{array}$ & RNA & $\begin{array}{c}\text { Tartof et al. } \\
\text { [24] }\end{array}$ \\
\hline 3 & $\begin{array}{c}\text { Janssen (Johnson \& } \\
\text { Johnson):Ad26.COV2.S }\end{array}$ & Yes & 85 & $\begin{array}{l}16 \text { trails in } 18 \\
\text { countries }\end{array}$ & $\begin{array}{l}\text { Non-replicating } \\
\text { viral vector }\end{array}$ & $\begin{array}{l}\text { WHO } \\
{[25]}\end{array}$ \\
\hline 4 & $\begin{array}{c}\text { Oxford/AstraZeneca: } \\
\text { AZD1222 }\end{array}$ & Yes & 127 & $\begin{array}{l}50 \text { trails in } 23 \\
\text { countries }\end{array}$ & $\begin{array}{l}\text { Non-replicating } \\
\text { viral vector }\end{array}$ & $\begin{array}{l}\text { Voysey et al. } \\
\text { [26] }\end{array}$ \\
\hline 5 & $\begin{array}{l}\text { Serum Institute of India: } \\
\text { Covishield }\end{array}$ & Yes & 47 & 2 trails in 1 country & $\begin{array}{l}\text { Non-replicating } \\
\text { viral vector }\end{array}$ & $\begin{array}{l}\text { Voysey et al. } \\
\text { [26] }\end{array}$ \\
\hline 6 & Bharat Biotech: Covaxin & Yes & 12 & 7 trails in 1 country & Inactivated & $\begin{array}{c}\text { Thiagarajan et al } \\
\text { [27] }\end{array}$ \\
\hline 7 & Sinopharm (Beijing) & Yes & 72 & $\begin{array}{l}9 \text { trails in } 10 \\
\text { countries }\end{array}$ & Inactivated & $\begin{array}{l}\text { Zhang et al. } \\
\text { [28] }\end{array}$ \\
\hline 8 & Sinovac: CoronaVac & Yes & 46 & $\begin{array}{l}26 \text { trails in } 8 \\
\text { countries }\end{array}$ & Inactivated & $\begin{array}{c}\text { Jara et al. } \\
\text { [29] }\end{array}$ \\
\hline 9 & $\begin{array}{l}\text { Zyduscadila } \\
\text { ZyCoV-D }\end{array}$ & No & 1 & 5 trials in 1 country & DNA & $\begin{array}{l}\text { Momin et al. } \\
{[30]}\end{array}$ \\
\hline 10 & $\begin{array}{l}\text { Gamaleya } \\
\text { Sputnik V }\end{array}$ & No & 74 & $\begin{array}{l}22 \text { trials in } 7 \\
\text { countries }\end{array}$ & $\begin{array}{l}\text { Non-replicating } \\
\text { viral vector }\end{array}$ & $\begin{array}{c}\text { Baraniuket al. } \\
{[31]}\end{array}$ \\
\hline 11 & $\begin{array}{l}\text { Serum Institute of India } \\
\text { COVOVAX (Novavax } \\
\text { formulation) }\end{array}$ & No & 2 & 2 trails in 1 country & Protein subunit & $\begin{array}{c}\text { Serum Institute } \\
\text { of India Pvt. Ltd. } \\
{[32-34]}\end{array}$ \\
\hline
\end{tabular}

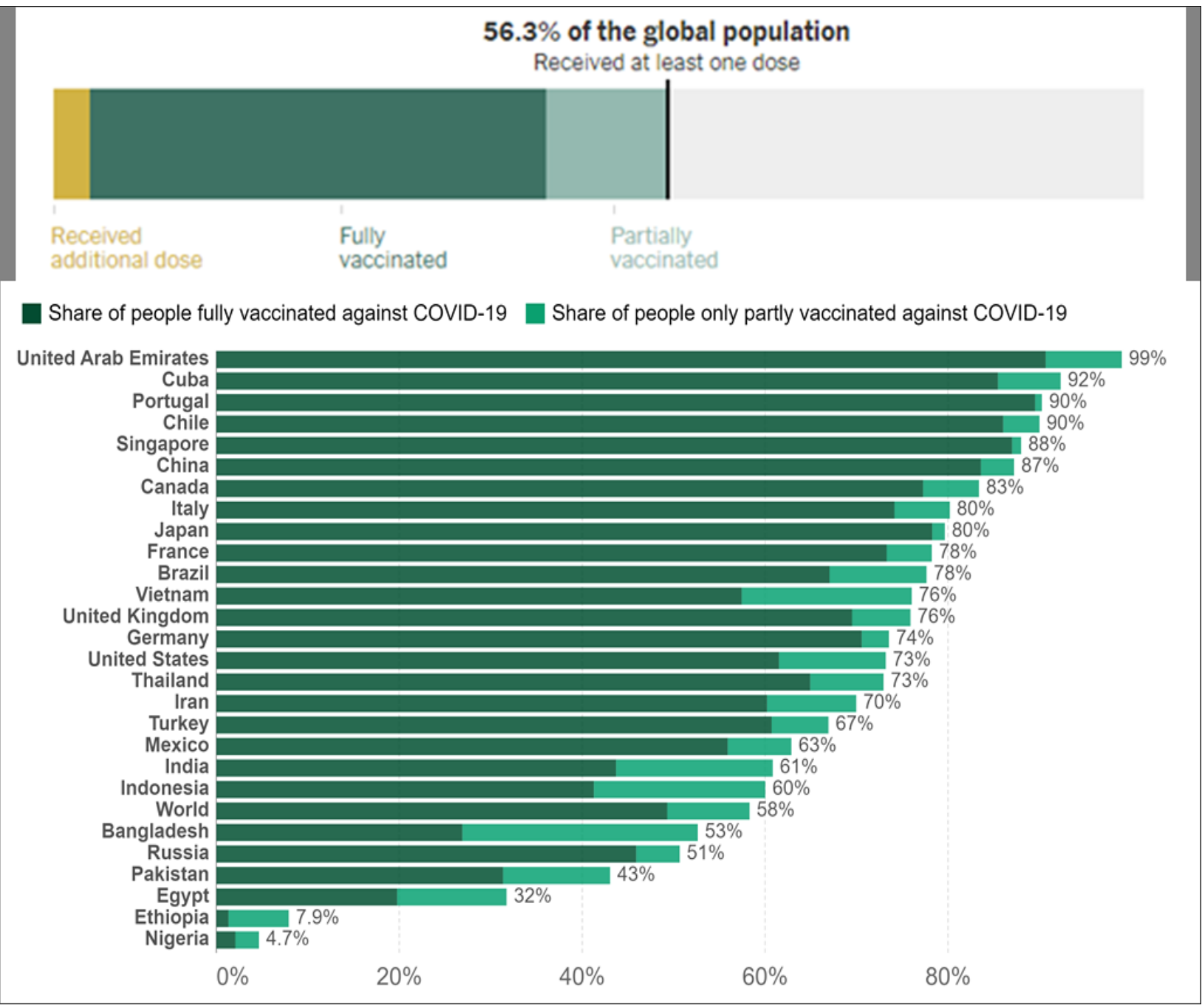

Figure 4. Vaccination data of all over the world up to date 


\subsection{Various Vaccine Effects on Different Variants}

The vaccines had a high level of neutralization against the original SARS-CoV-2 mutation, as expected. According to Pfizer, antibodies from patients who had previously been vaccinated with the two-dose Pfizer vaccine showed a significant loss in neutralizing power against Omicron, with a 40-fold decrease in neutralizing ability19.Infection with the Omicron form is predicted to cause severe sickness, hospitalization, and death. Current immunizations are intended to protect against this. Breakthrough infections are more likely to arise in patients who have been fully immunized. Vaccines against other variations, such as Delta, have proven to help reduce severe disease, hospitalizations, and death. The new appearance of Omicron highlights the significance of immunization and boosters even more. Scientists were working on it; still, they have not revealed which vaccine is effective for the omicron variant. Some medications are likely to remain helpful despite Omicron's changing genetic make-up, and some may be less successful. The expected risk frequency order of omicron variant mentioned below; high to low

\section{Not vaccinated people $>$ partially vaccinated $>$ fully vaccinated $>$ booster dose vaccinated}

\section{Conclusion}

This paper concludes with little idea about the omicron variant in different aspects than previous variants. The Omicron has a higher mutation capacity than earlier variants, leading to a high rate of spredability and complete effects and severity of the variant yet to unknown. It will take a few more weeks to complete about it; so far one death was reported due to the omicron variant in UK, and we concluded that re-infection rate was also high in case of omicron, the conclusion of the study to be completely for public awareness about new variant. Above information also gave idea about what symptoms observed with Omicron, the effects of available vaccines, and treatment.

\section{Declarations}

\subsection{Author Contributions}

N.K. and S.K. helped to conceptualization, write, and discuss this review article. Throughout the writing of this review article, K.S.L. provided guidance. All authors have read and agreed to the published version of the manuscript.

\subsection{Funding}

The authors received no financial support for the research, authorship, and/or publication of this article.

\subsection{Acknowledgements} ideas.

The authors' sincere thanks to the Institute of Chemical Technology, Mumbai (India)to encourage this kind of

\subsection{Ethical Approval}

The manuscript does not contain experiments on animals and humans; hence ethical permission not required.

\subsection{Data Availability Statement}

Data sharing is not applicable to this article.

\subsection{Conflict of Interest}

The authors declare that they have no known competing financial interests or personal relationships that could have appeared to influence the work reported in this paper.

\section{References}

[1] Cowling, B. J., Park, M., Fang, V. J., Wu, P., Leung, G. M., \& Wu, J. T. (2015). Preliminary epidemiological assessment of MERS-CoV outbreak in South Korea, May to June 2015. Eurosurveillance, 20(25), 1-7. doi:10.2807/15607917.ES2015.20.25.21163.

[2] Wang, C., Horby, P. W., Hayden, F. G., \& Gao, G. F. (2020). A novel coronavirus outbreak of global health concern. The Lancet, 395(10223), 470-473. doi:10.1016/S0140-6736(20)30185-9.

[3] Cascella, M., Rajnik, M., Aleem, A., Dulebohn, S., \& Di Napoli, R. (2021). Features, evaluation, and treatment of coronavirus (COVID-19). StatPearls (NCBI Bookshelf).

[4] Centers for disease control and prevention CDC, SARS-CoV-2 Variant Classifications and Definitions. Available online: https://www.cdc.gov/coronavirus/2019-ncov/variants/variant-classifications.html (accessed on December 2021). 
[5] Zhou, B., Thao, T. T. N., Hoffmann, D., Taddeo, A., Ebert, N., Labroussaa, F. Beer, M. (2021). SARS-CoV-2 spike D614G change enhances replication and transmission. Nature, 592(7852), 122-127. doi:10.1038/s41586-021-03361-1.

[6] The Times of India, Covid-19: How Omicron uses spike protein to enter cells (2021). Available online: https://timesofindia.indiatimes.com/world/rest-of-world/covid-19-how-omicron-uses-spike-protein-to-entercells/articleshow/88056481.cms (accessed on December 2021)

[7] The Hindu, First death with Omicron variant in United Kingdom (2021). Available online: https://www.thehindu.com/news/international/first-death-with-omicron-variant-in-united-kingdom/article37950265.ece (accessed on December 2021)

[8] Krieger, B. L. M., Area, B., \& Group, N. (2021). Omicron vs. Delta : Comparing COVID’s most worrisome variants (pp. 4-7).

[9] Reuters, Explainer: How worried should we be about the Omicron variant? (2021). Available online: https://www.reuters.com/business/healthcare-pharmaceuticals/how-worried-should-we-be-about-omicron-variant-2021-12-14/ (accessed on December 2021).

[10] Özdemir, Ö. (2020). Coronavirus Disease 2019 (COVID-19): Diagnosis and Management (narrative review). Erciyes Medical Journal, 42, 242-247. doi:10.14744/etd.2020.99836.

[11] The Economic Times News "Bengaluru doctor infected with Omicron doing fine" (2021).Available online: https://economictimes.indiatimes.com/news/india/bengaluru-doctor-infected-with-omicron-doingfine/articleshow/88085676.cms (accessed on December 2021).

[12] Hindustan Times, Coronavirus digest: Omicron reported in 57 countries, WHO Reports (2021). Available online: https://www.hindustantimes.com/lifestyle/health/coronavirus-digest-omicron-reported-in-57-countries-who-reports101639015185312.html (accessed on December 2021).

[13] U.P.I.N. South Africa hits daily record 37,875 COVID-19 cases mostly by Omicron (2021). Available online: https://www.upi.com/Top_News/World-News/2021/12/12/coronavirus-south-africa-record-37875-cases/3181639318281/ (accessed on December 2021).

[14] India Today, With 78,610 new patients, UK sees highest ever daily Covid cases amid Omicron spread. Available online: https://www.indiatoday.in/coronavirus-outbreak/story/covid-omicron-uk-cases-1888313-2021-12-16 (accessed on December 2021).

[15] Hindustan Times, Coronavirus digest: Omicron reported in 57 countries, WHO Reports (2021). Available online: https://www.hindustantimes.com/lifestyle/health/coronavirus-digest-omicron-reported-in-57-countries-who-reports101639015185312.html (accessed on December 2021).

[16] European Centre for Disease Prevention and Control, Epidemiological update: Omicron variant of concern (VOC) - data as of 12 December 2021. Available online: https://www.ecdc.europa.eu/en/news-events/epidemiological-update-omicron-data-12december (accessed on December 2021).

[17] Indian Express, Covid-19 Numbers Explained: Omicron cases in US less than 1,500 but infections could be over six lakh (2021).https://indianexpress.com/article/explained/covid-19-numbers-explained-omicron-us-cases-7683032/ (Accessed on December 2021).

[18] Indian Express, Coronavirus News Highlights: Delhi reports nearly 500 new Covid cases, test positivity rate jumps to $0.89 \%$ (2021).https://indianexpress.com/article/india/coronavirus-news-live-omicron-modi-covid-vaccine-booster-7690706/ (accessed on December 2021).

[19] E Times News, Coronavirus: Are children at risk of developing severe Omicron infection? Available onlinehttps://imesofindia.indiatimes.com/life-style/health-fitness/health-news/coronavirus-are-children-at-risk-of-developingsevere-omicron-infection/photostory/88141222.cms (accessed on December 2021).

[20] Shen, K., Yang, Y., Wang, T., Zhao, D., ... Jiang, Y. (2020). Diagnosis, treatment, and prevention of 2019 novel coronavirus infection in children: experts' consensus statement. World Journal of Paediatrics, 16(3), 223-231. doi:10.1007/s12519-02000343-7.

[21] Medicines, T., \& Biotechnology, V. (2021). UK approves new Covid treatment, may work against Omicron variant (pp. 1-2).

[22] The New York Times, Pfizer's Covid Pill Works Well, Company Confirms in Final Analysis. Available online: https://www.nytimes.com/live/2021/12/14/world/covid-omicron-vaccines/pfizer-covid-pill-paxlovid (accessed on December 2021).

[23] Baden, L. R., El Sahly, H. M., Essink, B., Kotloff, K., Frey, S., Novak, R., Diemert, D., Spector, S. A., Rouphael, N., Creech, C. B., McGettigan, J., Khetan, S., Segall, N., Solis, J., Brosz, A., Fierro, C., Schwartz, H., Neuzil, K., Corey, L., ... Zaks, T. (2021). Efficacy and Safety of the mRNA-1273 SARS-CoV-2 Vaccine. New England Journal of Medicine, 384(5), 403-416. doi:10.1056/nejmoa2035389. 
[24] Tartof, S. Y., Slezak, J. M., Fischer, H., Hong, V., Ackerson, B. K., Ranasinghe, O. N., Frankland, T. B., Ogun, O. A., Zamparo, J. M., Gray, S., Valluri, S. R., Pan, K., Angulo, F. J., Jodar, L., \& McLaughlin, J. M. (2021). Effectiveness of mRNA BNT162b2 COVID-19 vaccine up to 6 months in a large integrated health system in the USA: a retrospective cohort study. The Lancet, 398(10309), 1407-1416. doi:10.1016/S0140-6736(21)02183-8.

[25] Agency, E. M., \& O, D. W. H. (2021). WHO adds Janssen vaccine to list of safe and effective emergency tools against COVID-19. Saudi Medical Journal, 42(4), 463-464.

[26] Voysey, M., Clemens, S. A. C., Madhi, S. A., Weckx, L. Y., Folegatti, P. M., Aley, P. K., Angus, B., Baillie, V. L., Barnabas, S. L., Bhorat, Q. E., Bibi, S., Briner, C., Cicconi, P., Collins, A. M., Colin-Jones, R., Cutland, C. L., Darton, T. C., Dheda, K., Duncan, C. J. A., ... Zuidewind, P. (2021). Safety and efficacy of the ChAdOx1 nCoV-19 vaccine (AZD1222) against SARSCoV-2: an interim analysis of four randomised controlled trials in Brazil, South Africa, and the UK. The Lancet, 397(10269), 99-111. doi:10.1016/S0140-6736(20)32661-1.

[27] Thiagarajan, K. (2021). What do we know about India's Covaxin vaccine? The BMJ, 373, 1-2. doi:10.1136/bmj.n997.

[28] Zhang, Y., Zeng, G., Pan, H., Li, C., Hu, Y., Chu, K., Han, W., Chen, Z., Tang, R., Yin, W., Chen, X., Hu, Y., Liu, X., Jiang, C., Li, J., Yang, M., Song, Y., Wang, X., Gao, Q., \& Zhu, F. (2021). Safety, tolerability, and immunogenicity of an inactivated SARS-CoV-2 vaccine in healthy adults aged 18-59 years: a randomised, double-blind, placebo-controlled, phase $1 / 2$ clinical trial. In The Lancet Infectious Diseases (Vol. 21, Issue 2, pp. 181-192). doi:10.1016/S1473-3099(20)30843-4.

[29] Jara, A., Undurraga, E. A., González, C., Paredes, F., Fontecilla, T., Jara, G., Pizarro, A., Acevedo, J., Leo, K., Leon, F., Sans, C., Leighton, P., Suárez, P., García-Escorza, H., \&Araos, R. (2021). Effectiveness of an Inactivated SARS-CoV-2 Vaccine in Chile. New England Journal of Medicine, 385(10), 875-884. doi:10.1056/nejmoa2107715.

[30] Momin, T., Kansagra, K., Patel, H., Sharma, S., Sharma, B., Patel, J., Mittal, R., Sanmukhani, J., Maithal, K., Dey, A., Chandra, H., Rajanathan, C. T., Pericherla, H. P., Kumar, P., Narkhede, A., \&Parmar, D. (2021). Safety and Immunogenicity of a DNA SARS-CoV-2 vaccine (ZyCoV-D): Results of an open-label, non-randomized phase I part of phase I/II clinical study by intradermal route in healthy subjects in India. In EClinicalMedicine (Vol. 38). doi:10.1016/j.eclinm.2021.101020.

[31] Baraniuk, C. (2021). Covid-19: What do we know about Sputnik v and other Russian vaccines? The BMJ, 372, 7-8. doi:10.1136/bmj.n743.

[32] Serum Institute of India Pvt. Ltd. (2020). COVISHIELD Completes Enrolment of Phase III clinical trials under partnership of ICMR and Serum Institute of India (pp. 1-2).

[33] Komalatha, N., Shilpa, G., Laddha, KS. (2020). Isolation of starch from curcuma longa and its characterization. International Journal of Pharmaceutical Sciences and Research, 11(11), 5712-17. doi:10.13040/IJPSR.0975-8232.

[34] Baswaraju, M., Komalatha, N., Anil Kumar, G., Raghuram Rao, A., Achaiah, G. (2018). Synthesis and evalution of new tacrine derivatives as anti-alzheimer's agents. International Journal of Pharmacy and Biological Sciences, 8 (1), 590-597.

[35] Mathieu, E., Ritchie, H., Ortiz-Ospina, E., Roser, M., Hasell, J., Appel, C., ... Rodés-Guirao, L. (2021). A global database of COVID-19 vaccinations. Nature Human Behaviour, 5(7), 947-953. doi:10.1038/s41562-021-01122-8.

[36] Dongala, T., Katari, N. K., Ettaboina, S. K., Krishnan, A., Tambuwala, M. M., \& Dua, K. (2021). In vitro Dissolution Profile at Different Biological pH Conditions of Hydroxychloroquine Sulfate Tablets Is Available for the Treatment of COVID-19. Frontiers in Molecular Biosciences, 7. doi:10.3389/fmolb.2020.613393.

[37] Katakam, L. N. R., Dongala, T., \& Ettaboina, S. K. (2020). Novel stability indicating UHPLC method development and validation for simultaneous quantification of hydrocortisone acetate, pramoxine hydrochloride, potassium sorbate and sorbic acid in topical cream formulation. Talanta Open, 1, 100004. doi:10.1016/j.talo.2020.100004.

[38] Katakam, L. N. R., Ettaboina, S. K., \& Dongala, T. (2021). A simple and rapid HPLC method for determination of parabens and their degradation products in pharmaceutical dosage forms. Biomedical Chromatography, 35(10). doi:10.1002/bmc.5152. 